\title{
PENTECOSTALISMO CATÓLICO E ENTRECRUZAMENTOS POLÍTICOS, TEOLÓGICOS E SOCIAIS COM A RENOVACÃO CARISMÁTICA CATÓLICA.
}

Fernanda Ferrari Palma

(UFGD/PPGAnt- f.ferraripsi@ @otmail.com)

\section{RESUMO}

ESTE ARTIGO ABORDA A HISTÓRIA DE UM MOVIMENTO DA IGREJA CATÓLICA DENOMINADO RCC, RENOVAÇÃO CARIAMÁTICA CATÓLICA, DESDE SUA FUNDAÇÃO NOS EUA ATÉ SUA CHEGADA AO BRASIL POR VOLTA DE 1967. APRESENTO A HISTÓRIA DA BEATA ELENA GUERRA, RESPONSÁVEL PELA REATIVAÇÃO DAS EXPERIÊNCIAS INTENSAS COM O SAGRADO DENTRO DO CATOLICISMO, CONSIDERANDO-A COMO POSSÍVEL MITO FUNDADOR DA RCC; E A RELAÇÃO COM O QUE SE PODE CHAMAR PENTECOSTALISMO CATÓLICO, TENTO EM VISTA A INFLUÊNCIA DO PENTECOSTALISMO NO CATOLICISMO CARISMÁTICO ATRAVÉS DAS VIVÊNCIAS DOS FENÔMENOS ATRIBUÍDOS À FIGURA DO ESPÍRITO SANTO. A RENOVAÇÃO CARISMÁTICA CATÓLICA EM SEUS 50 ANOS DE EXISTÊNCIA NO BRASIL SE TORNOU PALCO DE INÚMEROS ACONTECIMENTOS NO INTERIOR DA IGREJA CATÓLICA E EM TODO CONTEXTO SOCIAL E RELIGIOSO BRASILEIRO. A RAIZ PENTECOSTAL VISÍVEL NAS CARACTERÍSTICAS DE FERVOR EMOCIONAL E EXPERIÊNCIAS CORPORAIS PRESENTES EM SUAS PRÁTICAS RITUAIS TORNA POSSÍVEL COMPREENDER AS RESISTÊNCIAS DA INSTITUIÇÃO CATÓLICA EM RELAÇÃO A OUTRAS FORMAS DE RELIGIOSIDADES, BEM COMO A CONSEQUENTE LUTA POR FIRMAR SUA IDENTIDADE. COM A RETOMADA DA HISTÓRIA DO PENTECOSTALISMO SE RESGATA TAMBÉM REFLEXÕES SOBRE O CONTEXTO SOCIAL E POLÍTICO DA RCC NO CENÁRIO NACIONAL FRENTE AO SURGIMENTO DA TEOLOGIA DA LIBERTAÇÃO QUE CARACTERIZOU O MOVIMENTO DE ESQUERDA DENTRO DA IGREJA CATÓLICA; E A INFLUENCIA DOS CULTOS AFRO-BRASILEIROS NAS FORMAS DE LOUVOR ADOTADAS PELOS MOVIMENTOS PENTECOSTAIS E, CONTRADIZENDO A ESTE CENÁRIO DE HERANÇA E ELO, ESTÁ O INFINDÁVEL COMBATE ÀS RELIGIÕES AFRO-BRASILEIRAS TRAVADO PELO MOVIMENTO CARISMÁTICO CATÓLICO. O CAMPO RELIGIOSOCATÓLICO-CARISMÁTICO, OU DO "PENTECOSTALISMO CATÓLICO", ABORDADO NESTE ARTIGO, TROUXE A POSSIBILIDADE DE REFLETIR SOBRE O CONTEXTO HISTÓRICO, SOCIAL, POLÍTICO E INSTITUCIONAL QUE CONSTRÓI E LEGITIMA A PRÁTICA RELIGIOSA; A DIVERSIDADE DE OFERTAS RELIGIOSAS CONFIGURANDO UM CONTEXTO DE DISPUTA DE BENS SIMBÓLICOS; E A LIGAÇÃO SISTÊMICA ENTRE OS FATORES DIACRÔNICOS E SINCRÔNICOS, INTERNOS E EXTERNOS, VIVIDOS INDIVIDUALMENTE E COLETIVAMENTE NUMA EXPERIÊNCIA DE INSEPARABILIDADE.

PALAVRAS-CHAVES: RENOVAÇÃO CARISMÁTICA CATÓLICA; PENTECOSTALISMO CATÓLICO; DISPUTA DE BENS SIMBÓLICOS. 


\section{Nanduty}

ISSN:2317-8590

ABSTRACT

THIS ARTICLE ADDRESSES THE HISTORY OF A CATHOLIC CHURCH MOVEMENT CALLED CCR, CATHOLIC CHARISMATIC RENEWAL, FROM ITS FOUNDING IN THE USA UNTIL ITS ARRIVAL IN BRAZIL AROUND 1967. I PRESENT THE HISTORY OF BLESSED ELENA GUERRA, RESPONSIBLE FOR REACTIVATING INTENSE EXPERIENCES WITH THE SACRED INSIDE THE CATHOLICISM, CONSIDERING IT AS A POSSIBLE MYTH OF THE CCR; AND THE RELATION WITH WHAT CAN BE CALLED CATHOLIC PENTECOSTALISM, CONSIDERING THE INFLUENCE OF PENTECOSTALISM IN CHARISMATIC CATHOLICISM THROUGH THE EXPERIENCES OF THE PHENOMENA ATTRIBUTED TO THE FIGURE OF THE HOLY SPIRIT. THE CATHOLIC CHARISMATIC RENEWAL IN ITS 50 YEARS OF EXISTENCE IN BRAZIL HAS BECOME THE SCENARIO OF NUMEROUS EVENTS WITHIN THE CATHOLIC CHURCH AND IN EVERY BRAZILIAN SOCIAL AND RELIGIOUS ENVIRONMENT. THE PENTECOSTAL ROOT VISIBLE IN THE CHARACTERISTICS OF EMOTIONAL FERVOR AND BODY EXPERIENCES PRESENT IN ITS RITUAL PRACTICES MAKES IT POSSIBLE TO UNDERSTAND THE RESISTANCE OF THE CATHOLIC INSTITUTION TO OTHER FORMS OF RELIGIOSITY, AS WELL AS THE CONSEQUENT STRUGGLE TO ESTABLISH ITS IDENTITY. THE REESTABLISHMENT OF THE HISTORY OF PENTECOSTALISM RESCUES REFLECTIONS ON THE SOCIAL AND POLITICAL CONTEXT OF THE CCR IN THE NATIONAL SCENARIO BEFORE THE EMERGENCE OF LIBERATION THEOLOGY THAT CHARACTERIZED THE LEFT MOVEMENT WITHIN THE CATHOLIC CHURCH; AND THE INFLUENCE OF THE AFRICANBRAZILIAN CULTS IN THE FORMS OF WORSHIP ADOPTED BY THE PENTECOSTAL MOVEMENTS AND, CONTRADICTING THE SCENARIO OF INHERITANCE AND BOND, IS THE ENDLESS STRUGGLE AGAINST AFRICAN-BRAZILIAN RELIGIONS DEBATED BY THE CATHOLIC CHARISMATIC MOVEMENT. THE RELIGIOUS-CATHOLIC-CHARISMATIC FIELD, OR "CATHOLIC PENTECOSTALISM", DISCUSSED IN THIS ARTICLE, BROUGHT THE POSSIBILITY OF REFLECTING ON THE HISTORICAL, SOCIAL, POLITICAL AND INSTITUTIONAL CONTEXT THAT BUILDS AND LEGITIMIZES RELIGIOUS PRACTICE; THE DIVERSITY OF RELIGIOUS OFFERS CONFIGURING A CONTEXT OF DISPUTE OF SYMBOLIC GOODS; AND THE SYSTEMIC CONNECTION BETWEEN THE DIACHRONIC AND SYNCHRONIC FACTORS, INTERNAL AND EXTERNAL, LIVED INDIVIDUALLY AND COLLECTIVELY IN AN EXPERIENCE OF INSEPARABILITY.

KEYWORDS: CATHOLIC CHARISMATIC RENEWAL; CATHOLIC PENTECOSTALISM; DISPUTE OF SYMBOLIC GOODS. 


\section{Nanduty}

ISSN:2317-8590

\section{BEATA ELENA GUERRA COMO POSSÍVEL MITO FUNDADOR DO "PENTECOSTALISMO CATÓLICO"}

É interessante pensar o mito de Elena Guerra como movimento fundador do pentecostalismo católico à medida que demarcou o retorno à intensidade das experiências com o sagrado na pessoa do Espírito Santo.

Nascida na cidade de Lucca- Itália, em 23 de junho de 1835, Elena Guerra, beata, atualmente vem sendo estudada com a possibilidade de ser canonizada por seus feitos já quase reconhecidos pela igreja católica como milagres.

Em abril de 1870, decide viver uma vida consagrada, fundando uma congregação que se dedicava à educação cultural e religiosa da juventude feminina. Este trabalho fez com que aumentasse sua devoção ao espírito santo, que se manifestava através de algumas experiências místicas e apelos internos, como descreve Reinaldo Bezerra dos Reis: "Vão colocando em seu coração uma acentuada inquietude em relação à condição bastante precária que se podia notar, na igreja, no tocante à devoção e ao culto à pessoa do Espírito Santo" (REIS, 2009: 14).

Através de cartas dirigidas ao Papa Leão XIII, chamadas de "Escritos de Fogo", Elena relata sua agonia pela pouca atenção dada à pessoa do Espírito Santo. Sensibilizado com seus escritos, o Papa, também beato, abre o Concílio Vaticano II consagrando o século XX como o "Século do Espírito Santo". Após a morte do Papa, Elena Guerra passa por grande sofrimento, e morre em 1914, sendo declarada beata em 1959 por João XXIII. Elena e o Papa Leão XIII são considerados figuras proféticas do pentecostalismo católico.

O Papa Leão XIII ficou reconhecido pelo pensamento social com o qual influenciou a igreja, num momento crítico para os povos de quase todo o mundo, que começavam sentir os efeitos da Revolução Industrial, da redefinição de fronteiras internacionais e a consolidação de ideologias político-econômicas. Para Reis, a vida eclesial do século que se iniciava seria marcada por profundas transformações atribuídas pela igreja, ao Espírito Santo (REIS, 2009: 22).

Há relatos de duas histórias diferentes marcando o início das experiências místicas atribuídas ao Espírito Santo ao estilo de Pentecostes: experiencia mística de falar em línguas 


\section{Nanduty}

ISSN:2317-8590

vivenciada pelos apóstolos quando estavam reunidos em oração, relatada na Bíblia Católica. O ponto de convergência entre os relatos está no fato de terem acontecido na mesma noite em lugares diferentes.

Segundo relatos descritos no Livro "Escutai o Espírito Santo" de Reinaldo Bezerra dos Reis, na noite de primeiro de janeiro de 1901, enquanto o Papa consagrava o século XX ao Espírito Santo, um pastor chamado Charles Fox Parham, reunido com seus alunos em vigília de oração e estudo bíblico, em Topeka Kansas, nos Estados Unidos, presenciou o sinal do "batismo no Espírito Santo" em sua aluna Agnes Nevada Ozman, ou seja, a oração em línguas/glossolalia. Sendo este o primeiro registro público deste tipo de manifestação que se tem nesses tempos. Embora para muitos este tenha sido o evento original do pentecostalismo, Reis ressalta que:

... o evento fundante do pentecostalismo clássico passou, em certo momento da história, a ser relacionado com os acontecimentos registrados cinco anos mais tarde, em Los Angeles, Azuza Street, envolvendo as atividades do Pastor negro Willian Joseph Seymour- que foi discípulo de Parham- ainda que para muitos o evento original seja de fato aquele da igreja de Topeka acima citado ( REIS, 2009:23).

Entende-se que para o catolicismo, a primeira manifestação de pentecostes se deu através das experiências e relatos de Elena Guerra, embora também seja considerada por outras religiões como fundadora do pentecostalismo.

Embora, como assinala Reis, acima, o marco em relação a movimentos coletivos de reavivamento espiritual, se deu no ano de 1906 em Los Angeles, numa rua que ficou muito conhecida por seus cultos ao Espírito Santo, a Azuza Street, onde foi comemorado o centenário do pentecostalismo em 2006, cujo evento participaram cerca de 30.000 pessoas. Neste evento, Jack Willian Hayford- um pastor muito popular responsável por várias pregações e escritor de dezenas de livros- lançou um livro entitulado: "The Charismatc Century" (O Século Carismático), onde enfatiza o papel das cartas de Elena Guerra ao Papa Leão XIII.

Como se percebe, a história de Elena Guerra se apresenta como mito fundador do pentecostalismo não só para a população católica da qual ela fazia parte, mas para todo movimento religioso que considera as manifestações vivenciadas por ela como ação do Espírito 


\section{Nanduty}

ISSN:2317-8590

Santo e cultivam a cultura de pentecostes como uma anunciação de um signo divino que se manifesta através de inspirações, intuições discernidas à luz da oração, resultando nos dons de serviço e/ou carismas.

Alguns escritos apontam a época em que aconteceram de forma sincrônica tais manifestações, enfatizando as condições sociais, religiosas, e situações históricas de grande relevância: como duas guerras mundiais, o genocídio dos judeus, a ocupação comunista, a guerra "fria", as novas conquistas da ciência, a crescente liberalização dos costumes.

As pessoas adeptas ao movimento de renovação interpretam o que aconteceu com a Beata Elena Guerra, com a aluna de Pharman, Agnes Nevada, com os alunos do retiro de Duquesne, com os fervorosos frequentadores da rua Azuza, bem como com todos os outros que se submeteram à este estilo de oração, como sendo "sinais" da presença do "Espírito Santo".

Nestes termos, a influência da Beata, motivou e inspirou a assembleia conciliar manifestada pelo Papa João XXIII, ou seja o Concílio Vaticano II, a partir do qual se configurou o movimento da Renovação Carismática Católica.

A vivência deste mito fundador se apresenta hoje na RCC através das pregações- que sempre enfatizam a história inicial da manifestação do Espírito Santo, como também, nas experiências místicas pessoais, que possuem as mesmas características de fervor e revelações de mensagens espirituais que trazem conforto e sentido, como se verifica nos relatos das intercessoras: pessoas com dom e responsabilidades por orar por outras pessoas.

Nesta perspectiva, Elíade (1969) aponta que os mitos não são criações arbitrárias, mas narrativas de profundas experiências humanas em busca de sentido. $\mathrm{O}$ autor valoriza os mitos à medida que "refletem sujeitos e situações históricas enquanto documentos religiosos que possuem uma situação existencial e fazem parte do espírito humano". Para ele, mito e existência são intrínsecos no ser humano, ressaltando que, o que interessa na religião é a experiência com o sagrado e não necessariamente a existência de Deus e a vivência da fé.

Souza se reporta à ideia de uma ontologia religiosa, sugerida por Mircea Eliade como um novo humanismo que objetiva solucionar as crises existenciais modernas: 


\section{Nanduty}

... por mais que o ser humano moderno negue a dimensão do sagrado e do mito, os conteúdos e estruturas no inconsciente estão na estrutura do humano em sua condição religiosa... Isso acontece pois, o inconsciente é o resultado de inúmeras experiências existenciais, não pode deixar de assemelhar-se aos diversos universos religiosos (ELIADE apud SOUZA 2011:171).

Desta forma, o simbolismo inserido nessas narrativas míticas, sugerem soluções existenciais que, segundo Elíade, "é resultado de um processo dialético que pode ser denominado por manifestação do sagrado" . O autor afirma ainda que:

A crise existencial tem sua solução na religião de onde vem a revelação recebida de um outro mundo, tornando a existência aberta a valores que não são contingentes nem particulares, permitindo assim ao homem ultrapassar as condições pessoais e, no fim das contas, alcançar o mundo do espírito (ELIADE, 2001:171).

O mito de Elena Guerra, muito presente na RCC até os dias de hoje, vem sendo celebrado desde 2015 até 2017- onde acontece o triênio de preparação para a o jubileu de ouro da beatificação da madre Elena Guerra e do pronunciamento de João XXIII a respeito de "Um novo pentecostes", juntamente com o jubileu de ouro da própria RCC. Isso reafirma o nascimento do movimento concomitante às manifestações do Espírito Santo na vida da Beata.

\section{DEFINIÇÃO E HISTÓRIA DO PENTECOSTALISMO E DO “PENTECOSTALISMO CATÓLICO”}

O Pentecostalismo é um movimento de renovação que acontece dentro do cristianismo, cuja ênfase é a experiência direta com Deus através do Batismo no Espírito Santo: um momento de novo nascimento onde o crente acredita receber a presença do Espírito Santo como "habitação", o tornando apto a experimentar os dons espirituais descritos na Bíblia.

Para os pentecostais, uma primeira evidencia física do batismo no espírito é o falar em línguas, a glossolalia, seguido de outros dons, como palavra de sabedoria (capacidade de fornecer orientação sobrenatural em decisões); palavra de conhecimento, fé, cura, milagres, profecia 


\section{Nanduty}

ISSN:2317-8590

(pronunciamento de uma mensagem de Deus); discernimento de espíritos (capacidade de discernir a ação de "maus espíritos"); e interpretação de línguas.

O termo Pentecostal é derivado de pentecostes: termo grego ligado histórica e simbolicamente ao festival de colheitas judaico, que acontece cinquenta dias depois da Páscoa e uma das celebrações mais importantes do calendário cristão, pois segundo esta crença, o Espírito Santo desceu sobre os apóstolos de Jesus Cristo e sua mãe Maria (quando estavam reunidos no cenáculo, lugar que fícou estabelecido como sagrado) sob "línguas de fogo" os capacitando a falar em línguas diferentes das suas e a curar enfermos.

Pentecostes era inicialmente uma celebração agrícola, relacionada ao cultivo e colheita do trigo, cevada e outros produtos. Posteriormente foi levada para lugares de culto, como o Templo de Jerusalém.

A ancestralidade pentecostal se inicia então com a passagem contida no Novo Testamento, em Atos dos Apóstolos 2 que descreve a descida do Espírito Santo sobre os Apóstolos e é reforçada por Paulo, em I Cor 12, 1-31, que constitui a base da fé dos Cristãos, onde os crentes entendem que seu movimento reflete o mesmo tipo de poder espiritual, estilo de adoração e ensinamentos da igreja primitiva:

Há diversidades de dons mais um só espírito, os ministérios são diversos, mais um só Senhor. Há também diversas operações, mais um só Deus que opera tudo em todos. A cada um é dada a manifestação do espírito para proveito comum... Mas um e o mesmo Espírito distribui todos esses dons, repartindo a cada um como lhe apraz. Porque como o corpo é um todo tendo muitos membros, e todos os membros do corpo, embora muitos, forma um só corpo, assim também Cristo. Em um só espírito fomos batizados todos nós, para formar um só corpo, judeus ou gregos, escravos ou livres; e todos fomos impregnados do mesmo Espírito (BÍBLIA, 1989: 1476).

O Pentecostalismo é um termo amplo e os pentecostais estão inseridos em vários grupos cristãos, não existe uma organização central ou igreja central que define o movimento; e a Renovação Carismática Católica é um desses movimentos adeptos ao reavivamento espiritual que constitui a marca do Pentecostalismo. 


\section{Nanduty}

ISSN:2317-8590

Como descrito acima, este movimento nascido nos EUA contou com a adesão de alguns membros protestantes, possuindo, a grosso modo, duas vertentes: uma branca e uma negra, ambas vindas do metodismo, marcando um novo modelo de cristianismo desde a Reforma. Este novo modelo marcou tanto a igreja católica quanto o protestantismo.

O primeiro a desenvolver a doutrina de pentecostes foi Charles Fox Parham (1873-1929), branco, ministro metodista, que reconhece a glossolalia como sinal que comprova o batismo no Espírito Santo. Em 1900 funda uma escola bíblica que denominou de Betel, em Tópeka, Kansas onde reunia seus alunos para estudarem sobre o batismo no Espírito Santo, utilizando somente como livro a Bíblia e em momentos de fervor, começaram as manifestações de falar em línguas estranhas.

O primeiro registro do "falar em línguas", na escola de Parham, se deu na virada do ano, quando numa reunião de orações e preces, enquanto aguardava a vinda do novo século, uma de suas estudantes, Agnes N. Ozman Laberge (1870-1937), em estado de êxtase, falou em línguas estranhas. Posteriormente, outros alunos e o próprio Parham passaram pela mesma experiência. Tais acontecimentos eram interpretados por Parham como uma terceira bênção, o que o estimulou junto a seus alunos a saírem em caravanas para outras regiões dos Estados Unidos.

Tais experiências se divulgaram rapidamente causando um forte impacto no meio universitário, difundindo-se então, por todos os continentes, onde ganhou força, tornando-o mundialmente conhecido, passando por modificações e se institucionalizando anos depois.

O movimento baseia-se na experiência pessoal com Deus, pela força do Espírito Santo e seus dons, afim de que todos se tornem discípulos de Jesus Cristo. Tal experiência de origem mística e subjetiva integra sensações corpóreas e efeitos emocionais vivenciados individualmente e/ou coletivamente, através de oração, louvor, pregação, adoração ou qualquer outra forma que a RCC utiliza para sensibilização provocando abertura para que "Deus possa agir e curar".

A experiência do "Batismo no Espírito Santo" é uma experiência mística íntima da manifestação do espírito santo na vida daquele que crê, sendo considerado um momento de 


\section{Nanduty}

ISSN:2317-8590

conversão, um recomeço na vida de quem experimentou e que, a partir deste fato, viverá sob uma nova orientação.

William Joseph Seymour (1870-1922), negro, ex-aluno de Parham, testemunha ocular do acontecido em Tópeka, após ter sido convidado a pregar para uma pequena comunidade em Los Angeles, de onde foi expulso, se instala num antigo templo da Igreja Metodista Africana, localizado na Azuza Strett, 312, que estava desativado, tornando-se um marco histórico para o Pentecostalismo. No dia 6 de abril de 1906, acontece a histórica experiência do falar em línguas, sob a liderança de Seymour, quando um menino de oito anos falou em línguas, seguido de outras pessoas [iniciando-se assim], pelo menos formalmente, o movimento pentecostal.

Esse grupo, liderado por Seymour, ficou conhecido como "Missão Apostólica da Fé” e, posteriormente, "Assembléia de Deus", cujas características eram a informalidade, a música alegre, as experiências de êxtase; e devido ao seu crescimento chamou a atenção da imprensa que na época "atribuiu a experiência desse grupo a um processo de africanização da cultura americana, divulgando esse movimento nacionalmente" (SIEPIERSKI, 2001:43).

Assim, aos poucos, esse movimento iniciado por Parham, de pequeno, torna-se um gigante com William Seymour, ganhando fama e extrapolando para além da Azuza Street, após espalharse por todos os EUA, rompe as fronteiras alcançando o mundo inteiro.

Embora possa haver certa dificuldade em situar em que momento surge de fato o Pentecostalismo, se com Parham, com o batismo de Agnez Osman, ou se com Seymour, com o batismo do garoto de oito anos, o certo é que há algo em comum a esses dois nomes, importantes para o nascimento desse movimento, que é a centralidade do batismo do Espírito Santo e de seu sinal físico que o evidencia, o falar em línguas estranhas (glossolalia), que na atualidade, juntamente com o dom de cura, dão acentuada característica aos movimentos pentecostais atuais como o neopentecostalismo e a Renovação Carismática Católica.

Embora tradicionalmente o pentecostalismo seja considerado proveniente do metodismo, se faz importante explicar o campo onde circulam os discursos e posições ideológicas. 


\section{Nanduty}

ISSN:2317-8590

Embora o pentecostalismo tenha se manifestado simultaneamente no meio branco com Charles Parham (1901) e nos meios negros com Willian Seymour (1906), percebe-se sua dimensão africana que, segundo Corten, há três elementos que justificam esta influência no pentecostalismo: geográfico, histórico e antropológico.

Um estudo realizado por Barret, em 1982, mostra que quanto à dimensão geográfica, os pentecostais se desenvolvem em todo o terceiro mundo de forma geral, mas em particular na África, na Coréia do Sul e nas Filipinas; e que se apresentam em maior número na África onde haviam laços históricos entre os primeiros missionários pentecostais e os fundadores das igrejas independentes na África do Sul, na África do Oeste, em Gana, na África Central (CORTEN, 1996:53).

Iain MacRobert, em seu livro "As raízes negras e o nascimento branco do primeiro pentecostalismo nos Estados Unidos", pontua que o metodismo tornou-se um fenômeno africano pelo modo como foi vivido nas igrejas negras antes e depois da abolição da escravatura; pois as experiências religiosas eram vividas segundo o prisma das religiões africanas, não se limitando a demonstrar que o "verdadeiro" fundador do pentecostalismo foi o pastor negro Seymor (MACROBERT apud CORTEN, 1996). O autor acima pontua:

O pentecostalismo tira seu verdadeiro nome do espírito de pentecostes, o contrário do segregacionismo. Este espírito, segundo MacRobert, explica a propagação do movimento a partir da missão de Azuza Street de Seymour. Contudo, isto não impedirá a Assembleia de Deus- prósperas nos meios brancos- de continuar sendo a mais importante igreja pentecostal (CORTEN 1996:49).

Esta perspectiva mostra a segregação racial em que se encontravam os negros em relação aos brancos.

Em relação ao ponto de vista antropológico, se percebe a influência africana nos clamores, respostas na forma de antífonas, cantos repetitivos, glossolalia, aplausos, batidas de pés, tripúdios, saltinhos, balanço do corpo, dança e outros gestos, que são praticados nas religiões da África Ocidental. 


\section{Nanduty}

Segundo o autor acima, a participação de negros nos retiros espirituais durante os séculos XVIII e XIX era maior do que de brancos, isto o leva à hipótese de que os comportamentos religiosos africanos, como o entusiasmo demonstrado durante os cultos, influenciavam os brancos. Assim, sob a influência das religiões africanas, o sentimento assume um aspecto mais corporal.

É importante ressaltar a característica dinâmica deste movimento que vai se transformando conforme as influências que recebe das diferentes culturas:

Origem africana? Origem metodista? O pentecostalismo é um fenômeno religioso transnacionalizado. $\mathrm{O}$ metodismo não foi simplesmente exportado sob a forma de pentecostalismo. Por um lado ele era "contaminado constitutivamente" por elementos africanos. Por outro, o pentecostalismo do Terceiro Mundo- em particular o Pentecostalismo brasileiro- teve quase sempre um desenvolvimento autóctone. Estes dois aspectos de contaminação constitutiva e de "desenvolvimento nativo" são as marcas não de uma exportação mais de uma transnacionalização (CORTEN, 1996:54).

Por ser um movimento dinâmico, o fenômeno pentecostal apresenta mudanças constantes e tendências novas. Paul Freston em seus estudos sobre o pentecostalismo, o vê como um movimento ativo do fenômeno protestante e não como uma categoria independente deste, mas parte de um movimento histórico do protestantismo mundial que foi dividido em três fases: o puritanismo, o metodismo e a terceira, o pentecostalismo. A partir da dinâmica desta terceira fase, também é dividida por Freston e definida em seus movimentos como "ondas". Assim sugere que o pentecostalismo no Brasil passou por três ondas, contando com os três momentos históricos (FRESTON, 1999: 329).

O pentecostalismo clássico foi definido como a primeira onda que data de 1910 a 1950, período de fundação e domínio da Congregação Cristã do Brasil e Igreja Assembléia de Deus, cujas características principais eram a crença no Espírito Santo, sectarismo radical, o anticatolicismo e rejeição aos "valores do mundo". A segunda onda foi chamado de Deuteropentecostalismo ou Agências de Cura Divina, em 1951 com a Igreja do Evangelho Quadrangular através do missionário Harold Willians. 


\section{Nanduty}

ISSN:2317-8590

A terceira vertente seria a Neopentecostal tendo início na segunda metade dos anos 70 , cujas principais igrejas são a Igreja Universal do Reino de Deus, a Internacional da Graça de Deus, a Comunidade Sara Nossa Terra e a Renascer em Cristo.

De acordo com Mariano, o uso da metáfora "onda" nos EUA, cunhado na década de 70, é comum para classificar distintos movimentos de "renovação" de linha pentecostal designando as ramificações pentecostais das igrejas protestantes, movimento que posteriormente foi nomeado de "carismático". Para o autor, as igrejas que compõem este movimento não podem ser definidas como seitas, por não se tratarem de grupos fechados, rigorosos, exigentes, ascetas, virtuosos. Ao contrário, o mesmo defende que são organizações abertas e em função disso, sugere mais apropriado denominar socialmente o pentecostalismo ou neopentecostalismo como "movimento" (MARIANO, 2005:81).

As influências em sua origem, bem como as transformações ocorridas neste movimento, aponta para a referida transnacionalização ocorrendo no próprio interior do Brasil, através da "guerra das religiões" que o pentecostalismo trava contra as religiões afro-brasileiras, contra umbanda e candomblé, contra os cultos, resíduos da escravidão. Aliás, vale lembrar que essas religiões afro-brasileiras não são apenas resíduos da escravidão, mas alimentadas por um contato constante com a África, laços mútuos entre os dois lados do Atlântico.

As crenças que operam nesses cultos afro-brasileiros estão relacionadas à forças da natureza, envolvendo os participantes e os levando ao transe que, segundo Corten, pode ser comparado ao estado alterado de consciência que experimentam os que "falam em línguas". Como esta realidade era chocante para os católicos que se formaram nos moldes europeus, isto tem a ver menos com o catolicismo do que com o pentecostalismo. Daí vem as grandes contestações e resistências da igreja católica a este estilo mais expressivo e emocionado de oração e vivência da fé.

O que se percebe neste contexto é que o pentecostalismo nega e ao mesmo tempo reconhece às práticas afro-brasileiras quando reproduz e, contraditoriamente, abomina suas manifestações, ao lutar e negar todas essas crenças, práticas e rituais, trava, na visão de Corten, um "diálogo afiado" com elas (CORTEN, 1996: 60). O momento crucial deste confronto acontece na prática do exorcismo principalmente, quando o demônio é convocado pelos 


\section{Nanduty}

ISSN:2317-8590

pentecostais e identificado com os orixás das religiões afro-brasileiras, como observado nos rituais de cura e libertação que acontecem na Renovação Carismática Católica estudada e nos demais registros de pesquisas de campo realizadas com esta população.

Embora seja mais agressivo o discurso sobre demônio nos movimentos pentecostais e na RCC, a religiosidade católica como um todo, inclusive a própria teologia da libertação utiliza o demônio, no caso, para designar os males sociais que oprimem os pobres: o desemprego, a fome, a prostituição, as crianças de rua, as drogas, etc. Isso tanto nas igrejas quanto nos meios televisivos que atingem um número maior de pessoas.

No Brasil, sem dúvida, embora Parham e Seymour sejam considerados fundadores do movimento pentecostal, o nome de maior expressão é o de W. H. Durham, por ter sido o responsável pelo envio ao Brasil dos missionários Luigi Francescon, Gunnar Vingren e Daniel Berg, fundadores das duas primeiras denominações pentecostais, em nosso país: a Congregação Cristã do Brasil e a Assembleia de Deus (AD), as duas já com mais de cem anos.

Após quatro anos do aparecimento do pentecostalismo nos EUA 1967, ele chega ao Brasil através dos três missionários citados acima: o italiano Luigi Francescon e os suecos Gunnar Vingren e Daniel Berg, membros da igreja de Durham, que fazia parte do movimento iniciado por Seymour. Francescon ficou conhecido pela fundação da primeira Igreja Pentecostal no Brasil, a Congregação Cristã do Brasil, em 1910, em São Paulo, e logo depois, Vingren e Berg, pela fundação da Igreja Assembleia de Deus, em 1911, no Pará.

Efetivamente a RCC é um movimento da igreja Católica Apostólica Romana, que teve sua inspiração e origem a partir do acontecimento (retiro) nos Estados Unidos que ficou marcado como "fim de semana de Duquesne" (Pittsburgh, Pensilvania), no ano de 1967, quando professores e estudantes universitários se reuniram marcando o início da historia do movimento, devido a vários fenômenos de avivamento espiritual vivenciados por essas pessoas como manifestações do espírito santo: oração em línguas, repouso no espírito, práticas de curas, dons de profecias e interpretações. 


\section{Nanduty}

ISSN:2317-8590

O Espírito Santo, terceira pessoa da santíssima trindade, significa para os adeptos da RCC, o consolador, conselheiro que habita dentro de cada pessoa, concedendo-lhe também seus dons (habilidades), tais como: dons de profecia (que geralmente acontece através de visões, sensações e/ou intuições), línguas, discernimento, sabedoria, cura, fé, milagres e ciência, sendo comum a prática desses dons durante os grupos de oração, assim como se acredita ter sido concedido nos tempos apostólicos.

A experiência característica deste encontro então se dá num nível corporal e emocional: sensações de êxtase, alegria, euforia, desejo de falar, louvar, cantar ou gritar, chorar, sensações de calor, às vezes repouso (o corpo se entrega à uma espécie de adormecimento).

Tais experiências se reproduzem com tanta frequência e intensidade que leva os sujeitos a desejarem cada vez mais este contato com o sagrado em busca das sensações que ele promove no corpo e nas emoções, numa dinâmica de retroalimentação.

Pedro Ribeiro de Oliveira, em sua pesquisa de campo sobre a RCC, realizada em 1975, identificou algumas características importantes no movimento, entre elas está a predominância feminina, a prevalência de adultos que provêm da classe social "letrada", igual ou superior ao ensino médio, notando que entre os coordenadores a maioria possui nível superior e a maioria é composta por leigos, principalmente leigas (OLIVEIRA, 1978:13).

Segundo Oliveira, a mensagem central do carismatismo católico está na ideia de que o “reino de Deus não está na vida depois da morte, mas começa já nesta vida, no coração de cada um", levando os participantes a uma visão de mundo otimista e a uma religiosidade intimista que se expressa na importância atribuída ao dom da cura (OLIVEIRA, 1977:28).

Na visão deste autor, a RCC é definida como um movimento de oração e se define pela valorização da oração e louvor e a experiência de fé, onde o tema da "vida nova", inaugurada pelo "batismo no espírito" e do "senhorio de Jesus" constituem seus dois temas básicos.

Apesar de serem os sacerdotes que dão ao movimento sua orientação, existe uma igualdade na recepção e no exercício dos carismas entre clero e leigos, onde muitos grupos possuem apenas 


\section{Nanduty}

ISSN:2317-8590

lideranças leigas, onde coordenadores, lideranças, ministérios e GOs, recebem a presença do sacerdote apenas em celebrações de missas.

Isto significa que a Renovação Carismática Católica funciona em grande parte sem a presença de padres em seu interior. Ela tem sua dinâmica própria que depende dos leigos que exercem as funções prescritas para a sua ordem: de coordenação dos ministérios, organização do Grupo de oração que constituem o coração da RCC; organização de formações, eventos e retiros, aos quais o padre é convidado à ministrar uma celebração ou uma pregação; que por sua vez, também é, na maioria das vezes, realizada por uma pregador leigo.

\section{RCC E A TEOLOGIA DA LIBERTAÇÃO: CONTEXTO SOCIAL E POLÍTICO}

Para melhor entender o contexto histórico pelo qual a RCC se deparou em seu início, vale ressaltar as várias versões narrativas sobre o que significava a teologia da libertação com sua opção preferencial pelos pobres adotada em Medellin, em seus vinte anos de efervescência, de 1964 a 1985, quando contrapunha os preceitos pentecostais e tradicionais da igreja católica.

Este fenômeno teve seu início nos anos 1960 por uma emoção pelos pobres, consequente da indignação ética dos teólogos da libertação, frente à pobreza na América Latina. Neste contexto, fazia-se uma analogia da crucificação com a paixão e a cruz dos pobres, lançando o apelo de partilhar esta paixão: "com-paixão".

Neste movimento participava a classe média, (diferente do movimento pentecostal que era basicamente ocupado pela classe baixa) onde a conscientização e a politização eram as características essenciais dos agentes pastorais.

O discurso teológico constrói uma categoria de "pobre" que aparece como sujeito dessa expressão emocional:

Uma estratégia de comunistas como pretendia o relatório Rockefeller de 1969? ou ao contrário um dispositivo da igreja para captar uma nova clientela? Uma estratégia de diferenciação de intelectuais frente aos leigos, frente aos outros teólogos, frente 


\section{Nanduty}

ISSN:2317-8590

à sociologia? Mais geralmente, um produto do movimento estudantil dos anos 60? Uma expansão ideológica da posição da igreja diante do estado autoritário? Uma expressão das comunidades eclesiais de base ou uma prática pastoral? Uma ameaça de cisma e/ou uma luta de poder no interior da igreja? Uma ideologia de ruptura com o iluminismo e com a romantização ou ao contrário uma versão renovada da doutrina social da igreja? Uma forma de autoridade carismática em oposição com as formas patrimoniais da hierarquia ou do poder secular ou a denúncia de toda autoridade? (CORTEN, 1996:12).

Para o autor acima a emoção pelos pobres torna-se uma força por ser suscetível de transformar a língua política que determina o que é aceitável numa sociedade. Sugere que paixão pela base é uma "construção emocional" que caracteriza a esquerda, o partido saído das lutas operárias de 1978-1979, próximo das CEBs e marcado pelo método de conscientização de Paulo Freire, onde aderem muitos intelectuais que haviam retornado do exílio.

Segundo Corten, esta construção ganha espaço e contribui para a formação de uma nova língua política:

Os militantes são numerosos a terem sido formados nas comunidades eclesiais de base, quer seja na pastoral operária ou na pastoral da terra... em 1982, muitos membros das CEBs candidataram-se gerais e em particular pelo PT. Uma paixão amadureceu na vida dessas comunidades: "a paixão pelo trabalho popular" (CORTEN, 1996:93).

O que chama a atenção nestas comunidades é que são formadas $60 \%$ por mulheres. As associações religiosas tem sempre um números elevado de mulheres, mas nas CEBs elas assumem um papel de liderança, sendo responsáveis pelas equipes de coordenação, além da animação; embora ainda nunca tenha chegado à disputar os mais altos cargos da hierarquia da igreja.

Este cenário abarca uma tripla topografia, pedagógica, teológica, marxista. A pedagogia, que é subvertida no final dos anos cinquenta pela problemática da conscientização de Paulo Freire, com o "ver, julgar e Agir", é adotado pela ação católica para fazer frente a influencia comunista crescente. 


\section{Nanduty}

ISSN:2317-8590

Assim nascem as primeiras Comunidades Eclesiais de Base- CEBs, que funcionam como círculos de conscientização: “o método Paulo Freire colocado em prática a plano nacional em 1963, é de fato um instrumento ideal de mobilização para o populismo" (CORTEN, 1996, p.24).

Este movimento de educação de base é interrompido pela igreja com a prisão de Paulo Freire, em setembro de 1964 (tendo ficado exilado na Bolívia e no Chile até 1969) visto que apoiava o golpe de estado.

A teologia se apresenta com duas correntes, uma conservadora e outra neoliberal, onde se forma a maioria dos teólogos latino-americanos, inclusive Leonardo Boff, que teve intensiva participação no movimento por uma igreja mais politizada e contextualizada socialmente. A corrente influenciada por Karl Barth, operava numa perspectiva Kierkegaardiana, pessimista, desprovida de esperança que "vê a cruz como expressão da negação de toda esperança e a ressurreição como negatividade da história” (CORTEN, 1996:25).

A outra corrente é mais otimista, aproxima a idéia de "reino de Deus" da história temporal, permite colocar a defesa da justiça na história da salvação. Esta teologia antropológica "liberal" é apoiada por João Paulo II e inspira profundamente o Vaticano II.

Embora os teólogos da libertação tenham se inspirado nessas duas correntes, o interesse maior era a libertação do eurocentrismo dessa teologia e das categorias abstratas e metafísicas, pois preferia as categorias sociológicas.

Gustavo Gutiérrez, visto como o pai da teologia da libertação, um padre peruano desenvolveu sua formação em Louvain e Lyon onde utilizava a sociologia no processo de reflexão teológica; conduzido por pensadores católicos franceses, desejava colocar a fé em relação com o mundo do século XX. Isto se estende por toda a América Latina, onde se abrem centros de sociologia religiosa, abrindo assim as perspectivas em relação ao pensamento europeu.

Yves Congar que teve papel eminente no Vaticano II, se simpatiza por este movimento e também demonstra abertura diante do protestantismo, suscitando desconfiança das autoridades eclesiásticas. Seu contato com Gutiérrez, fez com que este lhe fizesse várias referências em seus escritos no final dos anos 1950, época em que foi apresentado a Marx. 


\section{Nanduty}

ISSN:2317-8590

Neste movimento se apoia o terceiro plano do discurso, no marxismo, que influencia constitutivamente a teologia da libertação:

No início dos anos 60 uma espécie de substrato geral propagouse por toda parte, indo do movimento feminista às formas de partido único do Terceiro Mundo, passando pelas categorias do estado providência. Este substrato, empresta categorias do marxismo e está presente também na teologia da libertação (CORTEN, 1996:26).

A função latente desses movimentos é a mesma, de censurar a tendência à emoção, frente à miséria que os teólogos testemunhavam.

A categoria de "pobres" se tornou o conceito central e sobre a qual trabalha a teologia da libertação; e nesta posição perde a batalha para a hierarquia católica e para o pentecostalismo.

Segundo Carranza, apresentava-se então de um lado a ala progressista da igreja e de outro lado, os carismáticos pentecostais como opostos diante da ideia de transformar o mundo a partir da religião, ideia esta que encontra sua base no marxismo; e em relação à este, a RCC era considerada um movimento alienado, pois só olhava para o lado intimista, emocional e espiritual, negligenciando outros aspectos da realidade:

As análises weberianas deixavam claro que as CEBs alicerçavam sua visão ética do mundo, no paradoxo da racionalidade- organizar a vida e a conduta a partir de esquemas racionais que estabelecem o elo entre a crença e a necessidadeportanto, ser sensível às questões políticas e sociais era decorrência natural, a tempo que engajar-se nas práticas coletivas, sua consequência lógica (CARRANZA, 2009:46).

O contraponto fica visível na pesquisa realizada por Oliveira, em 1975, com RCC, onde reafirma que sua base está na "interioridade" da experiência religiosa, enfatizando a presença de Deus na vida e a importância do louvor; detectando que uma pequena porcentagem da população carismática investigada fala de amor ao próximo ou da renovação da igreja e do mundo. Assim o autor conclui que, no conjunto geral das mensagens, é visível o caráter interior de reavivamento espiritual. Para este autor, "o engajamento social é visto como consequência da renovação interior, esta vem em primeiro lugar em cronologia e importância" (OLIVEIRA, 1978:36). 


\section{Nanduty}

ISSN:2317-8590

Na visão de Corten, a igreja católica, a CNBB teve que reconhecer um lugar ao movimento da Renovação Carismática, pois não podia permitir que cinco ou seis milhões de católicos, migrassem para as igrejas pentecostais.

Esta não é a primeira vez na história que movimentos com forte carga emocional ganham popularidade. Também aconteceu a Idade Média e durante a Reforma, o pietismo e o metodismo, aos quais Corten denominou "romantismo teológico". Esta expressão diz respeito à religião da emoção e visa enfatizar que o efeito desse tipo de discurso teológico não leva à conscientização como esperavam os teólogos da libertação, mas a uma "devoção exuberante e insurrecional" (CORTEN, 1996:13).

Do outro lado da emoção, já que estamos tratando como categorias, está a perspectiva dialética marxista, onde o sagrado se une ao profano e mais, dialoga com o social e institucional, como se percebe, de uma forma mais integrada e menos excludente, como operam os conservadores que ficam somente com a emoção.

Nesta visão, a RCC era vista como uma religião que desviava o fiel para uma realidade meta-física e a-histórica, desvalorizando a reflexão crítica, refletindo a visão ideológica de dominação onde reforçava as dicotomias entre o sagrado e o profano e entre a vida religiosa e social (ROLIM, 1997).

Assim a lógica do Espírito Santo, onde se obtinha cura, milagres e libertação do demônio, era vista também como alienante, uma vez que acontecia individualmente, desgarrada do contexto social. Desta forma, colocavam-se em alianças ideológicas na esquerda: ateus, protestantes e católicos progressistas, e na direita: carismáticos e pentecostais (MARIANO, 1995).

Embora existam as diferenças entre carismáticos e pentecostais, como a Devoção à Nossa Senhora, o terço a Eucaristia e o Papa; ainda haviam mais semelhanças do que diferenças: a emoção, a moralidade sexual, êxtase, exorcismo e a maior parte dos participantes leigos. E diante desta realidade várias interpretações foram feitas sugerindo que a RCC foi a contenção da igreja católica, não só contra a teologia da libertação, mas contra o avanço pentecostal. Assim, 


\section{Nanduty}

ISSN:2317-8590

precisava demarcar suas fronteiras em relação a outros movimentos pentecostais e afirmar sua relação com a igreja católica, e para tanto, a devoção à virgem Maria demarca este território.

De 1972-1978, a hierarquia da igreja começa a manifestar sua rejeição à teologia da libertação devido aos elementos que as diferenciam da dita heresia popular: enquanto esta aspirava o contato direto com Deus, um acesso direto à bíblia e a valorização da pobreza à imagem de Cristo; a heresia erudita formada pelos teólogos da libertação e pelas CEBs pretendia difundir a bíblia, buscava outras formas de ação e de lugares de encontro durante a ditadura militar e entendia o crescimento da pobreza ligada à aceleração do processo de urbanização.

Segundo Corten a "heresia popular" tal como aparece na Renovação Carismática Católica foi recuperada por Roma para enfrentar a "heresia erudita" e, apesar de muitos obstáculos, a RCC se espalhou pelos EUA e pelo mundo; e foi no pontificado do Papa Paulo VI, sucessor de João XXIII, que conseguiu apoio do papado.

Parece, contudo, que a teologia da libertação também apresenta seu aspecto doutrinal, uma vez que compara os pobres à cruz e funda sua esperança na escolha feita por Deus para os excluídos e oprimidos, ou seja, articula libertação social e reino de Deus num tom romântico que, segundo Corten, "incita uma devoção de sofrimento e esperança pontuada de gritos de revolta", esta constitui a moral da salvação: o pobre que procura libertação (CORTEN, 1996:33). Dentro desta perspectiva Leonardo Boff defende que é preciso se converter pelo pobre latino americano, vivendo a paixão por este como se vivesse a paixão de Cristo.

Em relação aos dois setores que se desenvolveram dentro da igreja no contexto histórico da América Latina, um voltado para a espiritualidade e outro para a questão social e política, Oliveira pontua que o contraste deles se encontra na noção de libertação. Uma vez que esta noção foi intensamente empregada pelo setor militante da igreja, se referindo à libertação da opressão social, optando pela causa dos oprimidos e junto a eles construir a igualdade social, obtendo-se assim o "Reino de Deus", à medida que liberta o homem das injustiças. 


\section{Nanduty}

ISSN:2317-8590

Já a noção de libertação para a RCC, fala da libertação interior, ou seja, libertação dos pecados pessoais, males, angústias ou tudo que atormenta a pessoa. Nesta visão, observa Oliveira:

Ricos e pobres, oprimidos e opressores serão libertados interiormente na medida em que se entregarem ao senhorio de Jesus... Assim o reino de Deus é concebido como algo que se constrói no coração de cada um, na medida em que a entrega de cada um a Jesus vai operando sua libertação interior, da qual decorrerá naturalmente a libertação dos males exteriores (OLIVEIRA, 1978:87).

Percebe-se que a RCC foi se consolidando em meio a uma disputa no seio católico, diante da pluralidade de movimentos que o constituem, como exemplo, o Movimento de Comunhão e Libertação, nascido em 1969, as CEBs (Comunidades Eclesiais de Base), que ganharam efervescência nas décadas de 70 e 80 e, segundo Teixeira, encontraram inúmeras resistências, "mas sobrevivem à crise e ampliam o campo de interesse para novos desafios, como os da cultura, etnia, gênero, subjetividade, ecologia, espiritualidade, ecumenismo e diálogo interreligioso" (TEIXEIRA, 2010:21).

Vale ressaltar as condições sócio-históricas que permitiram o enraizamento da RCC no Brasil, ligadas ao proselitismo ofensivo (igrejas eletrônicas) e alianças políticas com setores conservadores da sociedade, principalmente norte americana; além do que, nesta mesma época, a igreja católica vivenciava as mudanças pós-conciliares que deram abertura aos grupos de revivência espiritual pautados na santificação pessoal.

A RCC ganhou força e visibilidade após o concílio Vaticano II (1962-1965), onde se definiu o século XX como o "século do Espírito Santo", que se iniciaria sob uma necessidade: O desejo de uma presença criadora e libertadora que é atribuída ao Espírito Santo. Dois anos após o término do Concílio, iniciaram as manifestações de pentecostes, que para os católicos é marcada pelo retiro dos jovens estudantes da Universidade de Duquesne.

Vale ressaltar que este é fruto de um longo processo de inserção do chamado protestantismo de missão, onde ingleses e principalmente norte americanos percorriam o Brasil já 


\section{Nanduty}

ISSN:2317-8590

no século XIX, se disseminando com maior força no contexto republicano do século XX, especialmente com a laicização empreendida pelo novo Estado Nacional.

Existem atualmente mais de 100 milhões de membros espalhados pelo mundo; e no Brasil, a Renovação Carismática teve início por volta de 1969, na cidade de Campinas-SP, através de encontros conhecidos como "Experiências do Espírito Santo" ou "Experiências de Oração", promovidos por Frei Haroldo Joseph Hahm, (Fundador das Casas de Recuperação denominadas "Fazenda Esperança", situadas no interior de São Paulo); Eduardo Doughety e George Kosickivindos dos Estados Unidos e colaborando para que os retiros e formações se expandissem rapidamente pela maioria dos estados brasileiros.

\section{DEMARCAÇÕES DA RENOVAÇÃO CARISMÁTICA CATÓLICA EM MEIO A OUTRAS OFERTAS RELIGIOSAS}

Em 1972, Frei Haroldo Rahm publicou uma das primeiras obras sobre o movimento no Brasil, chamada: "Sereis batizados no espírito", que explica o que vem a ser o "Pentecostalismo Católico". Esta obra funcionou como um marco da Renovação Carismática no Brasil, difundindo a forma de rezar ao Espírito Santo e colaborando com a expansão e formação de novos líderes, leigos e padres, entre eles o Monsenhor Jonas Abib, que em 1973 fundou a Comunidade Canção Nova.

Esta comunidade por manter um canal televisivo, talvez seja a mais conhecida comunidade carismática no Brasil, embora a maior comunidade carismática hoje é a Comunidade Xalom, que teve origem em Fortaleza, no Ceará e que também existe em muitas cidades brasileiras (sobretudo capitais) e em outras partes do mundo.

A organização inicial deste movimento no Brasil, se deu em 1973 com o Congresso Nacional, na Cidade de Itaicí- SP, e posteriormente, num segundo encontro, em 1974, sob a

coordenação do Padre Silvestre Scandian. Posteriormente, retiros, aprofundamentos e estruturação do trabalho através de um planejamento em nível nacional. 


\section{Nanduty}

ISSN:2317-8590

Um texto elaborado em maio de 1974, por uma equipe de 15 teólogos, sob a orientação do Cardeal Suenens da Bélgica, expressa a preocupação dos teólogos de afirmar o caráter católico da RCC. O documento chama-se "Orientações Teológicas e Pastorais da Renovação Carismática Católica" e revela o contexto institucional do movimento, afirmando seu desejo de continuar a tradição católica, admitindo que seus dons pertencem à natureza da igreja e que este movimento deve à autoridade pastoral a mesma obediência que qualquer outro católico. Na conclusão deste documento, os autores afirmam:

A renovação não visa criar no seio da igreja, um grupo particular, especializado no espírito santo e seus dons; procura, antes, favorecer a renovação da igreja local e universal pela redescoberta da plenitude de vida em Cristo pelo Espírito, o que inclui a gama completa dos dons (OLIVEIRA, 1978:62).

Esta preocupação em afirmar a catolicidade e a obediência à hierarquia da igreja, demonstra o esforço em fazer a RCC ser legitimada e, portanto, aceita pela instituição eclesiástica.

O grande sinal de que a RCC havia sido aceita pelo clero da igreja católica, foi obtido através do discurso do Papa Paulo VI em 19 de maio de 1975, a 15.000 participantes na ocasião do III Congresso Internacional da Renovação Carismática, que embora reafirmasse a necessidade da submissão do movimento à autoridade eclesiástica, deixa claro a importância da "renovação espiritual" que a RCC traz:

Nada é mais necessário a um mundo assim, cada vez mais secularizado, do que o testemunho desta renovação espiritual, que vemos o Espírito Santo fazer surgir hoje nas regiões e nos meios mais diversos. As suas manifestações são variadas: comunhão profunda das almas, contato íntimo com Deus na fidelidade aos compromissos assumidos no Batismo, numa oração muitas vezes comunitária, onde cada um, exprimindo-se livremente, ajuda, apoia e alimenta a oração dos outros e, na base de tudo, uma convicção pessoal que não tem sua origem apenas num ensino recebido pela fé, mas também numa certa experiência vivida, de que, sem Deus, o homem nada pode, e com Ele, pelo contrário, tudo lhe é possível... (OLIVEIRA, 1978:64).

Tal processo de aceitação da RCC por parte do episcopado brasileiro demorou mais de vinte anos, marcado por polêmicas e ambiguidades e só foi aceito pela maioria dos bispos do Brasil, através do documento que impunha muitas restrições à Renovação: 


\section{Nanduty}

ISSN:2317-8590

Desde suas origens, a RCC se debateu entre sua potencialidade carismática (autonomia dos leigos alicerçados na certeza de serem portadores também do sagrado, exercendo os dons e carismas do Espírito Santo) e a institucionalização do carisma. No entando, a RCC sucumbiu a rotinização e burocratização de sua capacidade de oposição ao sistema religioso estabelecido, tornando-se um movimento que vivencia o paradoxo entre a espontaneidade do carisma e a cooptação mediante mecanismos de controle da instituição eclesial (CARRANZA, 1998:48).

O que se percebe neste histórico é que a RCC só foi aceita pela maioria dos bispos do Brasil através do documento que impunha muitas restrições ao movimento, decorrente disso, a igreja foi percebendo que a RCC não se opunha a ela nem no carisma nem na obediência às regras institucionais, aliás, para Oliveira, este movimento se apresenta "muito menos renovador do que pretendia ser", mas que a diferença transparecia na relativa autonomia perante o bispo, uma vez que os grupos de oração aconteciam sem a organização e coordenação desta autoridade.

Para o autor acima, esta marca da autonomia se torna fundamental para pensar sociologicamente a RCC, pois suas indagações sugerem uma realidade, enquanto a prática do movimento obedece à outra:

... como ajustar os exercícios dos carismas à estrutura clerical da igreja Católica? Como um movimento onde qualquer leigo pode falar inspirado pelo Espírito Santo pode estar dentro de uma instituição religiosa, cuja marca sociológica é a radical diferença entre aquele que tem o poder de falar oficialmente em nome de Deus e quem não o tem? (OLIVEIRA, 1978:72).

Ao mesmo tempo em que isto justifica o grande estranhamento inicial por parte da igreja, o que se via na prática, era a aderência do movimento às mesmas regras impostas pela igreja, ou seja, nos grupos e eventos, a presença dos padres e ministros era a de destaque, revelando que a RCC mantém a estrutura clerical católica. Portanto ficava mais fácil a adaptação da igreja a este "novo", principalmente pelos benefícios que ele trazia.

Segundo Oliveira, as práticas religiosas da RCC são as mesmas que as do catolicismo romano, o que ela traz diferente é o modo de praticar e isso fica evidente nas reuniões de oração com seu fervor emocional, orações de petição e louvor, cânticos, e testemunhos. O que marca sua diferença entre outras formas de praticar o catolicismo, é a abertura à espontaneidade que este 


\section{Nanduty}

ISSN:2317-8590

movimento dá à seus participantes, permitindo a cada um seguir às inspirações recebidas pelo espírito santo.

Oliveira sugere em seus estudos, que a presença de teólogos desde o início do movimento deram a ele uma dimensão teórica que não corresponde à prática, dando primazia aos carismas e negligenciando os aspectos comuns à prática religiosa católica, como o incentivo ao sacramento. Assim, vários livros e artigos escritos e divulgados inicialmente pelo próprio movimento, formaram uma auto-imagem distanciada de sua prática, fazendo com que seu aspecto exótico ficasse em evidência.

Para o autor, o único aspecto que se exterioriza de forma diferente é a oração em línguas, que parece estar só em primeira vista fora do contexto católico, mas não deixa de ser uma oração totalmente sob o domínio do orador, o que difere é a pronuncia dos sons sem significado aparente, mas não se trata de descontrole emocional. O mesmo se aplica ao dom da profecia que atende às mensagens bíblicas de exortação, consolação e edificação as quais não denotam "novas revelações divinas", mas um esforço das mensagens religiosas contidas na Bíblia ou na tradição da igreja católica (OLIVEIRA, 1978:59).

Assim, mesmo que de forma demorada e parcial a RCC foi convencendo alguns bispos do Brasil e boa parte clero: "A América latina é um continente em ebulição onde a RCC nasceu num contexto de ditadura de guerra civil, de pobreza, de influencia norte-americana" (HÉBRARD, 1992:27).

A partir de 1980, a RCC consolidou-se institucionalmente, espalhando-se por todo o território nacional, inicialmente atingindo lideres engajados nos movimentos como Cursilho, Encontros de Jovens, vindo a ocupar um espaço significativo na mídia e, atualmente, a RCC encontra-se em todos os estados brasileiros contabilizando-se aproximadamente 60.000 o número de grupos de oração em todo o Brasil, existindo atualmente 198 grupos no estado do Mato Grosso do Sul e, precisamente, 30 na cidade de Dourados, segundo estimativa feita junto às coordenações estaduais da RCC (http://rccbh.com.br/CapelaVirtual_RCCBH.aspx/). 


\section{Nanduty}

ISSN:2317-8590

É na década de 1990 que a RCC ganha então maior evidência, contando com personalidades arrebanhadoras, que acabam por virar celebridades por sua popularidade, entre eles destacam-se: padre Marcelo Rossi, padre Fabio de Melo, os leigos Dunga, Valverde, Maria Del Rosário, Marcelo Braga. Há também os fundadores das pequenas Comunidades e dos grandes empreendimentos religiosos como o Pe. Jonas Adib (Canção Nova); Pe. Roberto Lettieri (Toca de Assis); André Luis Botelho (El Shaddai-Pantokrator); Denis Bourgerie (Santuário Maria Desatadora dos Nós); Moysés Louro de Azevedo e Maria Emmir Nogueira (Comunidade Shalom); Gilberto Gomes Barbosa (Obra de Maria).

Para efetivar a ofensiva nacional em todas as dioceses do país, a RCC contou com a organização de 15 secretarias que respondem pela execução específica deste projeto, "elas demonstram claramente a burocratização dos dons e carismas da RCC" (CARRANZA, 2000:59). Com tal organização, o trabalho da RCC ganha corpo, o movimento ganha visibilidade, segurando seus seguidores e tornando-os fiéis ao movimento, que investe na formação de seus seguidores.

Diante do crescimento da RCC, na $32^{0}$ Assembleia Geral da CNBB, em abril de 1994, começaram então a estudar e elaborar um projeto de orientações pastorais, propondo uma reflexão sobre o referido movimento, dirigida em especial aos fiéis que encontram nele meios de crescimento espiritual. O documento traz explicações sobre a presença do Espírito Santo no "ministério" e na vida da igreja, bem como os ensinamentos sobre a leitura e interpretação da Bíblia; e os dons e carismas a Ele atribuídos (CNBB, 1994: doc.53).

A RCC possui um Conselho Nacional formado por Bispos conselheiros- por recomendação da CNBB- e coordenadores dos estados, além de alguns convidados. Este conselho possui uma comissão nacional que é seu órgão executivo. O escritório Nacional da RCC fica sediado em Brasília, onde também se localiza a sede da CNBB.

O movimento hoje, no Brasil, se organiza nos seguintes "ministérios": Ministério de intercessão, ministério de oração pela cura e libertação, ministério da palavra, ministério de formação, ministérios da música, e ministérios de jovens, sendo sua principal missão o anúncio da palavra, da "boa nova", geralmente realizada em reuniões denominadas "Grupo de Oração" 


\section{Nanduty}

ISSN:2317-8590

(GO), sua matriz espiritual e organizacional, onde se segue a bíblia, o catecismo da igreja católica e todas as demais diretrizes, entre elas, os dogmas já fixados no catolicismo romano, como por exemplo, a crença na intercessão dos santos e a honra a Maria mãe de Jesus.

Sua função é percebida como a necessidade de "trazer a tona os carismas já presentes na igreja católica, mas às vezes em estado latente; isso sem tencionar sua relação com a instituição" (OLIVEIRA, 1977:27).

Esses grupos de oração acontecem nas dependências físicas da comunidade católica, sempre estimulados a permanecerem vinculados à instituição e ao Papa, obedecendo aos dogmas e doutrina da igreja católica, "aderindo à estrutura eclesiástica" (SOUZA, 1996:64).

O primeiro esforço acadêmico em direção à RCC no Brasil, data do ano de 1976, quando Dom Cipriano Chagas, apresentou à Pontifícia Universidade Católica do Rio de Janeiro (PUCRJ), sua dissertação se mestrado, onde apresentou os documentos da igreja que aprovavam a emergência da RCC e sua organização.

Em 1978 foi publicada uma pesquisa sociológica sobre a RCC pelo Centro de Estatística Religiosa e Investigações Sociais (CERIS), à pedido da CNBB, com descrição detalhada sobre sua organização, estrutura e proposta religiosa, onde foram feitos alguns apontamentos junto à teólogos da libertação sobre a não expansão da base social da RCC para além da classe média . O que contrariou esta ideia foi o fato dos carismáticos apresentarem, nos anos seguintes, um crescimento elevado e se configurarem em movimento de massas.

Em 1997, Reginaldo Prandi, publicou "O Sopro do espírito", fruto de suas pesquisas realizadas com a RCC na cidade de São Paulo analisando algumas dimensões do movimento face das transformações do campo religioso brasileiro nos últimos anos.

Em 1998 Brenda Carranza defende sua dissertação de mestrado pela Universidade Estadual de Campinas, abordando as origens, mudanças e tendências da RCC, de onde saem, posteriormente, vários artigos sobre o tema. 


\section{Nanduty}

ISSN:2317-8590

Uma das discussões mais importantes realizada pela autora acima, diz respeito à oferta de bens simbólicos travada pelo mercado religioso, onde segundo Carranza, o objetivo da RCC é "fazer da experiência religiosa uma mercadoria submetida às leis da concorrência no mercado de bens simbólicos", querendo imprimir sua oferta espiritual diante do público desgarrado do catolicismo, ou os católicos "só de nome”.

Segundo a autora, isso acontece devido ao crescimento da oferta religiosa: as religiões de perfil exotérico oriental, ao aumento rápido dos grupos evangélicos e os cultos afro-brasileiros ganhando visibilidade cultural; resultando numa espécie de "guerra santa" constante entre fiéis e "profissionais do sagrado":

Se, todavia, de um lado o campo religioso apresenta-se com esta ampla gama de opções simbólicas e ritualísticas que dão sentido à existência humana e permitem um trânsito religioso livre, por outro lado afloram traços de fundamentalismo e apelos de retorno à tradição, em alguns grupos, tano da RCC, quanto das igrejas pentecostais, que se esforçam em definir fronteiras identitárias (CARRANZA, 1998:40).

Diante das várias respostas oferecidas para o cultivo da dimensão religiosa, a disputa acontece não só entre religiões, mas no interior da igreja católica, sobre este aspecto afirma Mariz: "A Renovação não quer ser um movimento a mais dentro da igreja, mas transformar a igreja” (MARIZ, 2011:173). Por isso a RCC faz do pentecostalismo católico, um fenômeno religioso, onde muitos, através dela, se "estabelecem como profetas, místicos e mediadores da fé" (JESUS, 2013:5).

Assim o catolicismo começa a aparecer na condição de "mais uma" oferta religiosa entre outras, e não "a religião da cultura brasileira" como aponta Carranza. Neste sentido algumas categorias foram estudadas retratando a flexibilidade dos laços de pertença, são elas: adesão, conversão, prática religiosa, trânsito e sincretismo, que demonstram a percepção dos pesquisadores em campo, sobre fundamentalismo das doutrinas que se confrontam tentando estabelecer fronteiras; numa tentativa de privatização da crença religiosa. Ao mesmo tempo está a liberdade de escolha das pessoas que as permite participar de mais de um culto religioso. Desta 


\section{Nanduty}

ISSN:2317-8590

forma a RCC vem com a ideia de recuperar a hegemonia da igreja católica, surpreendendo com seu fenômeno religioso.

Mas desde o início se debate entre seu potencial carismático, como portadores do sagrado e a institucionalização do carisma. Este paradoxo entre a espontaneidade nas manifestações dos carismas e os mecanismos de controle que exerce sobre a instituição eclesial, com sua organização e burocracia, faz com que este movimento seja "uma igreja dentro da igreja" como aponta Carranza:

...uma sociedade dentro da sociedade; um modelo de igreja que se basta a si mesma, levando o fiel a um encasulamento, a refugiar-se do mundo, no movimento. Além disso, a RCC, em nome da experiência do Espírito que diz possuir e da renovação que oferece, pretende ser, segundo algumas de suas lideranças, a expressão da totalidade da igreja católica (CARRANZA, 1998:49).

Esta ideia de totalidade vai além, no imaginário e discurso do movimento, de um poder somente dentro da igreja católica. Nesta estratégia de afirmação de identidade, a RCC proclama que a igreja católica é a "verdadeira" igreja do mercado religioso brasileiro, reproduzindo o discurso demonizador e desqualificador do catolicismo em relação às outras formas de religiosidade brasileira: como o espiritismo kardecista, macumba, candomblé, os pentecostais e as religiões exotéricas.

Aqui fica evidente sua disputa no mercado religioso e uma de suas ofertas mais atraentes são os recursos oferecidos: de cura, libertação, milagres e exorcismo que se aproxima de uma religiosidade mais popular atraindo e ampliando seus adeptos para além da classe média. Dentro do catolicismo a RCC tomou a frente na produção de bens religiosos eletrônicos, assumindo esta missão com espírito profético, moralista e de neocristantade. Com a proposta de ganhar um espaço na TV brasileira e conter a ofensiva pentecostal, a CNBB apoiou a iniciativa dos leigos de criar o canal da família cristã, concretizado em 1995 com a criação da Redevida:

Assim, afinado com o padrão de produção catequético, moralizante, litúrgico, doutrinário e confessional, o televangelismo católico e o televangelismo carismático veiculam através de meios ultramodernos, um discurso tradicional da igreja católica, fazendo da televisão uma extensão das paróquias e dos 


\section{Nanduty}

ISSN:2317-8590

grupos de oração da RCC. Portanto paroquializando o espaço eletrônico a rede vida tende ser um canal para a terceira idade, tornando-a assídua consumidora de sacramentos via TV a cabo (FABRI, 1998:57).

Dentro desta perspectiva Religião-Modernidade, ocorrem as transformações internas da própria igreja católica, que passa pela tensão de circular entre os meios televisivos e tecnológicos (que a mesma condena) na tentativa de corresponder às demandas culturais do homens e mulheres contemporâneos; e manter a fidelidade a seus princípios doutrinários.

O apelo ao imaginário demoníaco, se torna também um instrumento de disputa, a partir da oferta de libertar o fiel dos males que ele causa, já que para a RCC ele é a causa de todos os males e problemas pessoais e sociais. Assim, promete reordenar a vida cotidiana dos fiéis a partir desta realidade, que explica os conflitos ignorando suas relações historicamente construídas. Através de um discurso proferido pelo Padre Jonas, pode-se perceber o elemento demoníaco como estruturante da realidade carismática:

De onde vem toda essa violência social que vivemos? Do dragão, do mal. De onde vem esta mágoa que você tem? Do dragão , do mal. De onde vem toda essa miséria e pobreza que vivemos? Do dragão, do mal. De onde vem a agressão entre marido e mulher? Do demônio meus irmãos. De onde vem toda essa sensualidade que está nos ares e toma conta de nós meus irmãos? Dele, do inimigo. De onde vem essa revolta, essa raiva dos jovens, dos filhos, dos adolescentes? Do inimigo. Não é de vocês, meus meninos e meninas, é do diabo. (Pe. JONAS Apud CARRANZA, 1998:51).

Mais um dos possíveis fatos responsáveis pela expansão da RCC, está na oferta de uma comunidade emocional que dá a possibilidade de experimentar curas físicas, interior, êxtase religioso, milagres e glossolalia, colocando o fiel em evidência possibilitando-o testemunhar suas experiências, aparecer em público, tirando-o do anonimato.

A respeito desses dois movimentos característicos da $\mathrm{RCC}$, a emocionalidade que promove experiências subjetivas e a burocratização que ao mesmo tempo que contem tais experiências, expande o movimento por sua organização e mobilização; Max Weber afirma que o carisma é "rotinizado" e que a intempestividade da "profecia" passa a ser controlada e domesticada. 


\section{Nanduty}

ISSN:2317-8590

Desta forma crescem as formas de expressão do movimento Carismático Católico, no início do século XXI, onde nascem as Novas Comunidades, num esforço por recuperar a evasão dos fiéis para outras religiões, principalmente pentecostais, visto que os dados do IBGE/2000 apontavam para o acelerado crescimento dessas religiões.

Estas novas comunidades aparecem como um novo gênero religioso e uma nova oferta, orientada pela emoção que tem como proposta tanto as questões morais, como na ideia de ressocialização, servindo como ponte entre o indivíduo e a sociedade e possibilitando atender às novas necessidades e à busca de sentido e orientação que sempre esteve latente na sociedade.

Nesta perspectiva, onde várias modalidades religiosas são oferecidas, a visão dos estudiosos é de que isso acarreta um grande peso para o indivíduo, por ter que, a todo momento, decidir, escolher, posicionar-se e consequentemente, "brota na sociedade pós moderna a insegurança como norma, o sentir-se perdido como espírito de época e o fundamentalismo como tábua de salvação" (CARRANZA, 2009:51).

Este cenário de concorrência religiosa, caracterizava o que Pete Berger e Pierre Bourdieu chamaram de "mercado de bens da salvação", que se dá com o fím do monopólio religioso católico, o grande investimento do pentecostalismo e neopentecostalismo e a maior abertura social a outras ofertas de bens simbólicos.

Hoje a RCC está presente em 258 países, 100 milhões de católicos participantes e milhares de grupos; compõe dezenas de experiência de vida comunitária denominadas Novas Comunidades de Aliança e de Vida, está também formando e estimulando a espiritualidade de padres e seminaristas.

A estimativa é que hoje, no Brasil, passe de 800 novas comunidades, cada uma com seu carisma, obedecendo ao objetivo e inspiração da igreja, após Vaticano II, de inserir-se no mundo "mesmo não sendo deste mundo". Para tanto conta com os ministérios que compõem sua base organizativa "ampliando sua ordem piramidal distribuída de forma hierarquizada e especializada, de Nacional para Estadual e Diocesana em Presidência, Conselho, Conselho Fiscal, Escritório 


\section{Nanduty}

ISSN:2317-8590

Administrativo, Órgãos de assessoria, ministérios de comissões, comissão executiva, até chegar em sua base social que são os Grupos de Oração.

Sobre este aspecto, Pierre Bourdieu em seu estudo "Gênese e estrutura do campo religioso" (1987), assim como Berger, afirma que uma das principais funções da religião é resolver o problema da precariedade e instabilidade das ordens sociais, para isso legitima instituições e "impõe um sistema de práticas e representações cuja estrutura objetivamente fundada em um princípio de divisão política apresenta-se como estrutura natural-sobrenatural do cosmos... com isso se obtem o efeito de absolutização do relativo e legitimação do arbitrário" (BOURDIEU, 1987:34).

Para o autor, a contribuição mais específica da religião para a manutenção da ordem social, já que a religião hoje é privatizada, se dá pela imposição de uma forma hierárquica de pensamento que, "por reconhecer a existência de pontos privilegiados tanto no espaço cósmico como no espaço político, naturaliza as relações de ordem" (BOURDIEU, 1987:71).

Segundo o pensamento de Pierre Bourdie, Jung Mo Sung, em um artigo sobre mercado religioso e mercado como religião, sugere que a lógica da economia de mercado tornou-se o modo de pensar "natural" nos dias de hoje.

Segundo Peter Berger, autor que propõe o conceito de "mercado religioso" em seus estudos sobre secularização, o pluralismo religioso surge como fato e como direito a partir da separação entre o Estado e a Igreja, onde ocorre o fim do monopólio religioso. Para o autor, neste contexto a religião é reduzida à esfera da vida privada, tornando-se um assunto de escolha pessoal ou familiar, tendo como consequência a competição entre as religiões, submetidas à lógica de mercado, em busca de mais fiéis ou de consumidores de bens religiosos.

Em sua obra O dossel sagrado, Berger afirma:

A característica chave de todas as situações pluralistas, quaisquer que sejam os detalhes de seu pano de fundo histórico, é que os ex-monopólios religiosos não podem mais contar com a submissão de suas populações. A submissão é voluntária e, assim, por definição, não é segura. Resulta daí que a tradição religiosa, que antigamente podia ser imposta pela autoridade, 


\section{Nanduty}

ISSN:2317-8590

agora tem que ser colocada no mercado. Ela tem que ser vendida para uma clientela que não está mais obrigada a comprar. A situação pluralista é, acima de tudo, uma situação de mercado. Nela, as instituições religiosas tornam-se agências de mercado e as tradições religiosas tornam-se comodidades de consumo. E, de qualquer forma, grande parte da atividade religiosa nessa situação vem a ser dominada pela lógica da economia de mercado (BERGER, 1985:149).

Dentro desta analogia, para o autor acima, a ideia de "mercado" está ligada à ideia de mercado capitalista, ou seja, não necessariamente está ligada ao atendimento das necessidades e desejos dos consumidores.

Percebe-se então que quanto menos regulação por parte do estado mais pluralismo e, portanto, mais disputa de mercado e oferta de bens religiosos; interagindo com a liberdade de escolha do indivíduo. Isto fala de uma antropologia da economia de mercado que, segundo Sung, está articulado com o surgimento de uma nova noção de ser humano: "o homo economicus, o homem reduzido a ser agente econômico que caucula racionalmente todas as suas opções em função de atingir o seu interesse próprio" (SUNG, 2014:296).

Segundo o autor acima, esta noção do homo economicus não leva em conta as diversas pessoas de diversas religiões que estão tão comprometidas com sua fé, que certamente se chocariam ao conceber a religião como um mercado. $\mathrm{O}$ mesmo pontua que a noção cristã da graça ou a budista da compaixão, são exemplos de valores humanos e religiosos que vão além do mero cálculo racional dos interesses próprios de poder ou riqueza.

Omerode, sobre o homem econômico racional, afirma: “as pessoas parecem cooperar com uma frequência muito maior do que a admitida pelos postulados do cáuculo racional do interesse particular" (OMERODE apud SUNG, 2014:298).

Parece evidente que muitas atividades religiosas do nosso tempo são realizadas sob a lógica do mercado capitalista, a questão é se podemos universalizar esta realidade. Ou melhor, perceber que existe um movimento das religiões com suas estratégias de atuação, ordem, mídia e interesses e de outro lado, o movimento de cada pessoa com sua experiência e motivação própria baseada em questões mais afetivas e menos racionais. 


\section{REFERÊNCIAS BIBLIOGRÁFICAS}

BERGER, Peter; LUCKMANN, Thomas. 2004. Modernidade, pluralismo e crise de sentido: a orientação do homem moderno. Petrópolis: Vozes.

BÍBLIA SAGRADA. 1989. Tradução dos originais mediante a versão dos Monges de Maredsous (Belgica). Editora Ave Maria, 65 edição, São Paulo.

BOURDIEU, P. 1996. Marginália: Algumas notas adicionais sobre o dom. Mana, outubro, vol.2, no.2.

1987. A economia das trocas simbólicas. $2^{\mathrm{a}}$ Ed. São Paulo: Perspectiva.

BORGES, Alexandre. A RCC no Brasil. Disponível em: http://www.portalcarismatico.com.br/menu/movimento/historia5.htm. Acessado em 2016.

CARRANZA DÁVILA, Brenda Maribel. 1998. Renovação Carismática Católica: Origens, Mudanças e Tendências. Campinas- SP: Dissertação de Mestrado, Universidade Estadual de Campinas, Instituto de Filosofia e Ciências Humanas.

2009. Novas Comunidades Católicas: Em busca do espaco Pós-moderno. Editora Idéias e letras, Aparecida-SP.

CNBB. 1994. Orientações Pastorais Sobre a Renovação Carismática Católica. Doc. 53, Brasília. CORTEN, André. 1996. Os Pobres e o Espírito Santo: O pentecostalismo no Brasil. Ed. Vozes, Petrópolis.

DAMACENA, Andréa Martins. 2004. Experiências religiosas: um estudo sobre mística e autonomianos discursos e práticas religiosas dos católicos e carismáticos. Tese de Doutoramento. Programa de pós-Graduação em Ciências Sociais da Universidade Estadual do Rio de Janeiro (UERJ), Rio de Janeiro.

ELÍADE, Mircea. 2001. O sagrado e o Profano. Martins Fontes, São Paulo. 1969. O Mito do Eterno Retorno. Edições 70. Lisboa.

FABRI, Marcio dos Anjos. 1998. Sob o Fogo do espírito. Ed Paulinas. São Paulo.

FRESTON, Paul. 1999. Protestantismo e democracia no Brasil. Universidade de São Carlos. http://www.lusotopie.sciencespobordeaux.fr/freston.pdf.

GUERRA, Lemuel. 2003. As influencias da lógica mercadológica sobre as recentes transformações da igreja católica. Revista de estudos da religião- REVER, São Paulo, n.2. Disponível em: http://www.pucsp.br/rever/rv2_2003/p_guerra.pdf. Acesso em: fev. 2017.

HÉBRARD, Monique. 1992. Os Carismáticos. Editora Perpétuo Socorro, Porto.

MACHADO, Maria das Dores Campos. 1996. Carismáticos e Pentecostais: adesão religiosa na esfera familiar. Autores Associados/ ANPOC, São Paulo.

MARIANO, Ricardo. 1995. Os neopentecostais e a Teologia da Prosperidade. Dissertação de Mestrado em Sociologia, Departamento de Sociologia, Universidade de São Paulo, São Paulo.

Edições Loyola, São Paulo. 1999. Neo Pentecostais: Sociologia do novo pentecostalismo no Brasil.

MARIZ, Cecília Loreto. A Renovação carismática Católica: uma igreja dentro da igreja. Disponível em: http://revistaseletronicas.pucrs.br/ojs/index.php/civitas/article/view/115. 


\section{Nanduty}

ISSN:2317-8590

2004. A Renovação Carismática Católica no Brasil: uma revisão

bibliográfica. InRodrigues, Donizete (org). Em nome de Deus: A revisão da Sociedade Contenporânea. Edições Afrontamento, Porto.

OLIVEIRA, Pedro A. Ribeiro. 1977. A Renovação Carismática Católica-notas de pesquisa. In: Cadernos do ISER, n.6, p.25-30, Rio de Janeiro.

- 1978. A Renovação Carismática Católica.Uma Análise

Sociológica Interpretacões Teológicas. Vozes, Petrópolis-RJ.

OLIVEIRA, Roberto Cardoso de. 2000. O trabalho do antropólogo. EditoraUnesp, 3 edição, São

Paulo.

Portal da RCC no Brasil: http://rccbh.com.br/CapelaVirtual_RCCBH.aspx

REIS, Reinaldo Bezerra. 2009. Escutai o Espírito Santo: Helena Guerra e João XXIII no século do Espírito Santo. Editora RCC Brasil, Porto Alegre.

ROLIM, Francisco Cartaxo. 1997. Dicotomias religiosas, ensaio de sociologia da religião. Vozes, Petrópolis-RJ.

SIEPIERSKI, Carlos Tadeu. 2001. "De bem com a vida”: O Sagrado Num mundo em transformacão. Tese de Doutorado Apresentada ao Departamento de Antropologia Social da Faculdade de Filosofia, da Universidade de São Paulo- USP, São Paulo.

SOUZA, André Ricardo. 2001. Padres Cantores, Missas Dançantes: A Opção da Igreja católica pelo espetáculo com mídia e marketing. Dissertação de mestrado- Faculdade de Filosofia e Ciências Humanas. Universidade de São Paulo, São Paulo.

SUNG, Jung Mo. 2014. Mercado Religioso e mercado como religião. Dossiê: Religião, Mercado e Mídia. Horizonte, v.12, n. 34, p.290-315, abr./jun. ISSN 2175-5841. Belo Horizonte.

TEIXEIRA, Faustino. $O$ catolicismo no Brasil. Disponível em: http://fteixeiradialogos.blogspot.com.br/2010/04/o-catolicismo-no-brasil.html.

VOLCAN, Marcos Dione Ugoski. 2003. Renovação Carismática Católica: uma leitura teológica e pastoral. Tese de Mestrado, Pontifícia Universidade Católica do Rio Grande do Sul. 